\title{
INSTRUMENTATION AND AUTOMATION IN THE SUGARCANE ETHANOL AGROINDUSTRY
}

\author{
Cristiane Sanchez Farinas, Ladislau Martin Neto \\ and Roberto Campos Giordano
}

\section{INSTRUMENTATION AND AUTOMATION IN THE OPTIMIZATION OF SUGARCANE ETHANOL PROCESS}

Despite the technological advances of the sugarcane industry in recent decades, there are still several opportunities to optimize the process and increase productivity in ethanol producing plants This is because ethanol distilleries in Brazil have given low investment priority to process control and automation. This fact could be related both to a slowdown in ethanol production in the late 1990's as well as poor understanding of the real benefits of implementing new technologies in the production process (ATALA, 2004).

With current scenarios on expanding the international ethanol market, the use of ethanol in flex fuel engines and in the processing of biodiesel, in hydrogen fuel cells and other alternative energy sources, it is expected an increase of investments in both research and implementation of new technologies, together with the automation and control of the production process (ATALA, 2004).

The implementation of a controlling system can contribute to increase process efficiency, productivity and reliability, reduce costs and reduce environmental impacts, and improve quality. One reason for this is that the key in fermentation processes for ethanol production, the microorganisms, are very sensitive to small environmental changes. Any small variation in the quality of the raw material, medium composition, $\mathrm{pH}$, and tem- perature can significantly affect their metabolism and change the efficiency and productivity of the process. The control of the bioprocess aims to maintain the environment in which the cells are cultivated in optimum conditions for growth, biosynthesis and final processing.

The control process for ethanol production follows the same principles of an industrial plant, aiming to keep certain variables at the desirable operational limits. To clarify the nomenclature used in this chapter, Figure 1 shows a symbolic representation of a generic system/process that will be used as a basis for the description of the terminology used in the context of control, automation and optimization of ethanol production.

The input variables of the system are classified into two types: disorders variables, the vector $\underline{\mathrm{d}}$, random in general (caused by uncontrolled changes in the environment), and controlled variables, $\underline{u}$, which are manipulated from control laws. Note that the variable $\underline{d}$ may or may not be measured.

The control variables, $\underline{\mathrm{u}}$, are manipulated variables in the real processes (usually by opening/ closing of valves, increase/decrease engine speed by using frequency converters etc.). In this case, it can be used different control strategies, being the most common the feedback control, where, once the state variables are known from measurements, it can be determined the value of $\underline{u}$ so that the process operates near a pre-determined condition (set point).

The response variables, or state variables, $\underline{x}$, are those variables defined by the model developer 


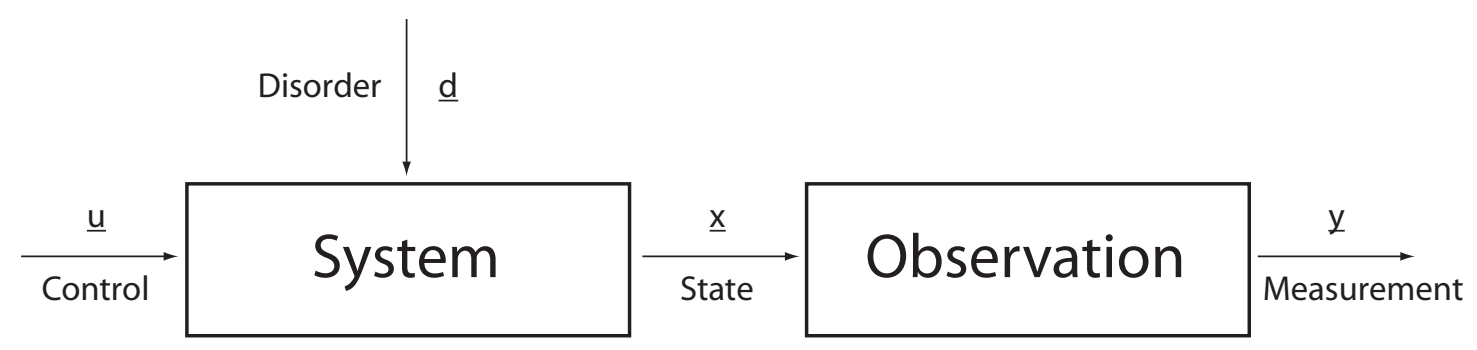

FIGURE 1 Representation of variables in a model of a monitored and controlled system/process.

as representing aspects of the reality relevant to the problem under study, in other words, are those calculated from the model equations (calculations that occur in the block "system"). Finally, the measured variables (or simply "measures"), ע, are those variables measured by the instrumentation available, both in real time (on-line) and off-line - for example, in an analytical center. It is important to note that the block "observation" includes equations, algebraic in general, that allows to have a problem as a function of $\underline{x}$ and $\underline{y}$. If the state variable can be measured directly, then this equation is simply $\mathrm{x}=\mathrm{y}$. Often, however, it is not possible, then you need to employ more complex relationships.

In the case of implementation of a controlling system in a fermentation bioreactor, certainly one of the state variables will be the cell concentration (typically, baker's yeast, Saccharomices cerevisiae). How to monitor the growth progress? For example, by optical density - OD of the medium, which would be one of the measures (part of the vector $\mathrm{y}$ ). In this case, a linear correlation is typically used in the block "observation": the calibration curve of cell concentration versus DO. However, this block may include more sophisticated computer algorithms, as mentioned later in the text about software sensors or soft-sensors.

The definition of input and output variables in Figure 1 is an abstract construction made by the modeler, assuming that the problem can be represented by a set of the most significant variables in terms of the application and the acceptable level of complexity required for the model. After all, a model is only a model, not the reality itself, and being clear about this fact is an essential starting point for discussing the importance of instrumentation and control in any case - and in particular the production of ethanol.

As can be seen from previous paragraphs, a requirement for an efficient process control is the use of an adequate monitoring methodology. Offline monitoring, performed by collecting samples and analyzing them subsequently, although it can provide accurate data, has the disadvantage of the delay between sampling and result.

Off-line monitoring is often used during the phase of development and validation of the process mathematical models, when there is a greater demand for the amount of information. Such models can then be used in the design, optimization and control of the process. For example, measurements of the composition of the medium by high performance liquid chromatography - HPLC would allow following those state variables (composition of the main substrates and products in the middle) but not in real time. These may be essential data to adjust the parameters of the fermentation kinetic models, but are not suitable for real-time process control, due to both the cost of the analysis and the delayed responses.

In turn, the real time monitoring of process relevant variables has the advantage of providing information with small delay relative to the intrinsic dynamics of the process. This approach provides information directly from the measurable variables, y (as shown in Figure 1), and is essential for early detection of problems/failures in the process, allowing for immediate action to be taken to revert the situation, while the process is still running. 
A flowchart for a typical sugarcane ethanol producing process can be divided into three steps: grinding, fermentation and distillation. During the grinding, the sugarcane juice is extracted. This juice is sent to the fermentation bioreactors, where the yeasts act in the transformation of sugar into alcohol. The product of fermentation, called the wine, is sent to distillation units for separating water and alcohol. Each of these steps offers opportunities for optimization. The real-time monitoring of all stages of the process of converting sugar into ethanol is of great importance to the effectiveness of the process as a whole.

However, controlling the fermentation step, for example, can be difficult due to the inability to directly measure some state variables (i.e., with $\underline{x}=\underline{y}$ ) fast enough to allow the implementation of control strategies, as the feedback control. That is the case, for example, of the measurements of the concentrations of substrate, product and biomass. Physical-chemical variables such as temperature and $\mathrm{pH}$, can now be measured on-line using appropriate sensors available in the market. However, to obtain information about the concentration of substrate, product and biomass it is usually necessary to take samples to be analyzed off-line.

Thus, an opportunity in instrumentation field to be emphasized is the use of spectroscopic techniques for real-time monitoring of these process components. Spectroscopic techniques are fast and non-destructive, require little or none sample preparation, and can be used simultaneously to evaluate different components in a complex mediums. One example of application are the studies being developed by VEALE et al. (2008) for the on-line monitoring of fermentation using infrared spectroscopy with Fourier transform - FTIR.

Chemical sensors have suitable characteristics for monitoring certain steps of the process. Features such as low cost, relatively simple instrumentation, minimal sample preparation and easy automation of measurements make of chemical sensors an attractive tool for industrial process control. However, the practical use of chemical sensors in a complex media is often hindered by their low selectivity. For example, only $\mathrm{pH}$ and dissolved oxygen probes are routinely used in bioreactors.

One of the new approaches to overcome problems of selectivity is the use of systems instead of discrete sensors. Such systems for analysis of liquids and gases are called electronic tongue and nose, respectively. They are able to perform both quantitative (concentrations of components) and qualitative analysis of a multi-component medium (RUDNITSKAYA and LEGIN, 2008). Several examples of applications of these sensors are reported in the literature, including the detection of sugars, metal ions and other organic and inorganic contaminants (BRUGNOLLO et al., 2008; CARVALHO et al., 2007; FERREIRA et al., 2007; RIUL et al., 2003; FERREIRA et al., 2003).

However, methods for real-time monitoring that are both robust and can be applied on an industrial scale are still relatively scarce because of difficulties related to the complexity of the composition of the sample and the specificity of the monitored components. A specific compound (e.g., a nutrient, metabolites, antibiotics) may have an important influence on cellular metabolism, even at very low concentrations. The measurement of these components in low concentrations, often in a complex medium, can also be a difficulty in bioprocess monitoring. Generally, isolation, purification, concentration and determination of these compounds are lengthy processes and are, therefore, carried out using off-line analytical methods (VOJINOVI et al., 2006).

As mentioned above, electrochemical sensors for $\mathrm{pH}$ and dissolved oxygen monitoring remain the most commonly used sensors in bioprocesses, but recent research have resulted in the improvement of optical sensors. Optical sensors for dissolved oxygen and carbon dioxide are now commercially available, as advances in optics and electronics are continuously reducing their costs (HARMS et al., 2002).

In the fermentation process, an issue that should be highlighted is the need for faster on-line methods for determining the quality of the feedstock (impurities content and composition). The standardization of a methodology to control the presence of organic and mineral matter in the raw 
materials used in fermentation and the streams of the fermentation process is another issue to be explored (FELIPE, 2006).

The separation/purification processes of ethanol (downstream) also have crucial importance in optimizing the overall process. The conventional process of distillation is energy intensive and integrated with other unit operations of the process, and generates sub products, including some that are very significant from the environmental point of view. The development of control systems for the distillation process, as well, and the evaluation of its effect on process performance through simulations are also a current demand.

An example of process upgrading is the use of molecular sieves in the production of anhydrous ethanol, instead of the azeotropic distillation and solvent recovery: these devices eliminate the need for the dehydrating cyclohexane allowing obtaining a product with higher purity and avoiding the need for disposal of this solvent.

The Center for Strategic Studies and Management - CGEE published a document (MACEDO, 2003) which lists some of the topics considered as important for development of industrial ethanol processing technologies (extraction, fermentation and distillation, production and energy use; analytical methodology; environmental control), and agro-industrial safety)

Several of these topics are directly related to instrumentation and automation, as follow:

- Automation: complementation of local systems and monitoring, development of sensors/equipment, smart operational controls.

- Analytical methodology: use of NIR spectroscopy on-line in the production line and to determine the quality of sugarcane.

- Fermentation: more robustness to adjust to fluctuations of feedstock quality.

- Use of new techniques for separation and concentration (membranes, ion exchange).

- Development of new products from sucrose (plastics, solvents, amino acids).

- Development of technologies for the recovery of straw at low cost $(<\mathrm{US} \$ 1.00 / \mathrm{GJ})$ and technologies for production of additional energy in the plants.

- Co-generation for electricity.

- Hydrolysis of cellulose for ethanol production.

The automation of an industrial plant is accomplished through the implementation of sensors and actuators, controlled by remote systems. The measurements of the sensors and the action of the actuators are carried by signals passing between a supervisory system and the plant. An automated plant, with the acquisition of process variables in real time and control strategies and set up, provides benefits to both the producer, with a reduction of complaints, returns, rework and costs, as to the final consumer, who has a product more standardized (ATALA, 2004).

Certainly, could greatly contribute to the optimization of ethanol production some techniques used in petroleum refineries, such as: real time optimization of thermoelectric balance systems, design automation techniques with tools involving electronic units, digital documentation systems, data acquisition systems, data reconciliation to close mass balance, advanced process control etc. These technologies are currently applied to the refining process and eventually could be incorporated into the sugarcane sector (OLIVEIRA, 2008).

Indeed, the use of techniques already known for analysis, synthesis, optimization and advanced control of sugarcane industry would be the interpretation of classical Bioprocess Systems Engineering that was developed due to a demand from oil and petrochemicals industries. This approach was recently described by PINTO (2008) and PINTO et al. (2009) for a cheese whey refinery, demonstrating the flexibility and capability of the technique for adaptation into the production of ethanol.

In conclusion, the current conceptual project methods, design and operation of ethanol plants should be reviewed for incorporating simulation techniques, optimization and process control. Tools that enable the implementation of methods for on-line analysis should be developed, serving as a support to this new methodology, in order to ensure a process more efficient in terms of economic, energy and environmental issues. 


\section{CELLULOSIC ETHANOL: INSTRUMENTATION AND AUTOMATION CHALLENGES}

Cellulose is the most abundant natural renewable resource of the planet and energy production based on the lignocellulosic matrix is an important alternative route that has been studied and debated worldwide. Sources of cellulosic biomass that can be used for energy production, especially in the form of biofuels, include sugarcane bagasse and straw. Although there are technologies available for cellulose processing, most of them are hindered by technical or economic difficulties. Nevertheless, some experts believe that the lignocellulosic biomass will be the main feedstock for ethanol production in the future.

The industrial production of biofuels is presently at what can be called a technological crossroad. A hard competition among different technologies will be in course in the near horizon. The winners will certainly be defined by a combination of economical criteria, environmental restrictions and process robustness. Table 1 summarizes some companies that are presenting different solutions for the production of biofuels (CORTRIGHT, 2008; RENNINGER, 2008).

A route that looks very promising for the production of second generation ethanol is the chemical or enzymatic hydrolysis of bagasse (and/

TABLE 1 Companies technological map: with biofuels production.

\begin{tabular}{|l|c|c|}
\hline Route & Biochemical & Thermochemical \\
\hline Hydrocarbons & $\begin{array}{c}\text { Amyris } \\
\text { LS-9 }\end{array}$ & $\begin{array}{c}\text { Choren } \\
\text { Shell/Virent }\end{array}$ \\
\hline Alcohols & $\begin{array}{c}\text { BP/DuPont } \\
\text { Coskata }\end{array}$ & \\
& $\begin{array}{c}\text { logen } \\
\text { Gevo }\end{array}$ & Range Fuels \\
& Mascoma & \\
& Verenium & \\
\hline
\end{tabular}

or straw), with simultaneous or sequential fermentation. This route, however, requires additional steps of material processing in order to convert the polymeric compounds present into fermentable sugars. This is due to the recalcitrant nature of lignocellulosic materials, which have inter and intra-molecular bonds that cause the hydrolysis of cellulose to be much more difficult than the hydrolysis of starch material, for example.

Among the hydrolysis technologies there are opportunities for development using chemical and enzymatic hydrolysis. The enzymatic conversion of lignocellulosic materials to obtain fermentable sugars has been identified as a promising and of great industrial interest to increase the ethanol productivity in a sustainable manner (OGIER et al. 1999; WYMAN, 1999; KNAUF and MONIRUZZAMAN, 2004).

However, the enzymatic hydrolysis route of cellulose, although an alternative of lower environmental impact, it still requires the development of technologies that can reduce the costs of enzyme production. The costs of cellulases production is considered to be one of the major constraints for the technological commercialization of the enzymatic hydrolysis of cellulose (WALKER and WILSON, 1991; EVELEIGH, 1987).

Another technological challenge to be faced is related to the pretreatment of biomass in order to reduce its recalcitrance. Along with the development of pretreatment processes that are efficient in terms of technical, economic and environmental aspects, an important technological demand is related to the development of robust analytical techniques. Techniques that allow a quick and easy characterization of the biomass composition are essential to define in advance the variables of the pretreatment and to facilitate the selection of the process, since there are different options and technologies and the appropriate choice depends on the type of feedstock.

In addition, the characterization of biomass is very important to create databases for the simulators to be used in the integration process and to define the possible routes for the biorefineries. Also of high significance is the actual development or adaptation of the simulators to incorporate the 
kinetic models characteristic of the process in question. This means extending the concept of classical Bioprocess Systems Engineering to the production of cellulosic ethanol.

The challenges are enormous, requiring considerable effort in research and development. This is due not only to the complexity of the microbial cultivation process. Even the enzymatic hydrolysis of lignocellulose has kinetic mechanisms much more complex than the classical catalysis. That is due to the fact that enzymes are molecules which catalytic action is not trivial, and in the case of hydrolysis of cellulose, there is a complex of enzymes acting synergistically on a complex substrate, and also the pretreatment process significantly alters its structural features - and therefore the reaction kinetics. Therefore, there is a strong demand for the development of modeling related to the enzymatic hydrolysis of cellulose. Models that describe the conversion rates based on changes in some properties of the substrate, such as the degree of polymerization, crystallinity and accessibility of cellulose are of interest.

The opportunities in instrumentation and automation for biomass characterization and enzyme production are presented in the following topics.

\section{Biomass Characterization}

The development of robust analytical methods is a key technological demand to assure the viability of cellulosic ethanol production, as well as for the implementation of biorefineries. This is due to the need to characterize the biomass quickly and accurately in order to define the operating conditions of the conversion process, since heterogeneity is an inherent property of biomass.

The chemical composition of biomass varies as a function of several factors, including plant genetics, environmental conditions during growth, and the method of harvest and storage. In addition, many sources of biomass to be used as a feedstock for the conversion processes are waste coming from other processes. This introduces another variable related to the efficiency of the original process as an additional source of variability in their composition (HAMES et al., 2003).
All this possible variability in biomass composition is difficult to control and is therefore of great importance to develop methods for rapid analysis in order to contribute to the evaluation of all steps of production and conversion, as follows:

- Genetics of plants for development of new cultivars: thousands of plants can be evaluated in its composition for selection of interesting mutations.

- Harvest: monitoring of field crops to determine the exact time to harvest.

- Purchase of raw material: the price of biomass can be based on quality, rather than weight.

- Storage: changes in the composition of biomass can be monitored as a function of time and storage conditions.

- Mixtures of raw materials (blending): supply of more uniform raw materials to the process.

- Composition of biomass: allow an adjustment of the process operating conditions according to the raw material supplied.

- Pretreatment: allow setting of reaction conditions to optimize the process according to the raw material being fed.

- Monitoring and Process Control: real-time information about the amount of enzyme and micro-nutrients that must be fed at appropriate temperature and $\mathrm{pH}$, allowing the optimization of operating conditions.

- Products: yield and quality of products available and supplied in real time.

In this context, the area of research in instrumentation has a great potential for the development of compact equipments and sensors with an application in the development of methodologies for a fast and accurate analysis of large amounts of materials. Also advanced methods that generate new information about the characteristics and properties of biomass and its components are opportunities in the instrumentation area.

Currently, the characterization of biomass can be made through various chemical methods, both destructive and non-destructive ones. The non-destructive methods are of great interest due 
to the fact that it is usually not required a prior processing for chemical separation of the material prior to the determination itself. However, chemical methods can be time consuming and expensive, making difficult its application in realtime monitoring.

Therefore, there is a great opportunity for the development of instruments and methodologies using spectroscopic methods for the characterization of cellulose, hemicellulose and lignin, both in processed and raw samples. Several spectroscopic techniques have been widely applied in studies of characterization, such as Electron Paramagnetic Resonance - EPR, Nuclear Magnetic Resonance - NMR, Fourier Transform Infrared - FTIR, Near Infrared - NIR and fluorescence (MARTIN-NETO et al., 2007).

EPR spectroscopy is one of the few laboratory methods that provide structural information without destroying the sample, allowing the same material to be used for further analysis (MARTIN-NETO et al., 1994, 2001). This technique is sensitive to paramagnetic materials, including species that have atoms or molecules with at least one unpaired electron, including into this category ions of transition metals and free radicals (BOLTON, 1994). Besides the identification of the paramagnetic ion, it is usually possible to identify its valence state, information of great interest for plants nutrition. EPR can also provide information about the nature and concentration of organic free radicals and paramagnetic metal ions, most of them plant micronutrients (Fe, $\mathrm{Cu}, \mathrm{Mn}, \mathrm{Mo}$ ) (LAKATOS, 1977; MARTIN-NETO et al., 1998, 2001; SENESI, 1990).

A valuable information on biomass characterization is the presence of lignin, which are known to have a high content of stable free radicals detectable by EPR (FITZPATRICK and STEELINK, 1972; CZECHOWSKI et al., 2004; FIALHO, 2007; FIALHO, et al., 2007) and generally it must be separated from the cellulose in some processes configurations for production of cellulosic ethanol.

Experiments with nuclear magnetic resonance spectroscopy - NMR in studies of solid samples are usually carried out using the technique of Variable
Amplitude and Cross Polarization and Magic Angle Spinning - VACP-MAS monitoring the nuclei of the isotope ${ }^{13} \mathrm{C}$. The information obtained from the NMR analysis are such as the degree of aromatic and aliphatic samples and structural characterization, and identification of compounds such as lignin, tannins, carbohydrates, alkyl groups, methoxylated, phenolic and carboxylic (STEVENSON, 1994; PRESTON, 1996). From the results of ${ }^{13} \mathrm{C}$ NMR novel information about the chemical modifications and structural aspects can be monitored according to the characteristics of biomass, allowing following processes hitherto unknown and which was until then empirically interpreted (GONZALEZ-PEREZ et al., 2004).

Another technique with potential applications in the characterization of biomass is infrared spectroscopy. This technique is based on the fact that different types of chemical bonds and molecular structures existing in a molecule absorb electromagnetic radiation in the infrared region at characteristic wavelengths and, as a result, the atoms involved enter into vibration (STEVENSON, 1994). The method is relatively affordable and the interpretation of the data is simple. However, in many situations, the overlapping bands may require complementary use of other analytical methods. There is currently a trend to associate statistical methods, such as chemometrics, to interpret the data generated.

The analysis of FTIR has been traditionally used to identify functional groups such as carboxyl, amine, hydroxyl, carbonyl and others (SCHNITZER and KHAN, 1978; STEVENSON, 1994; GONZALEZ-PEREZ et al., 2004; GONZALEZ-PEREZ et al., 1998; SAAB et al., 1998). This information is very useful because it allows the identification of possible processes of oxidation and modification of functional groups associated with the effects of treatment of biomass.

FTIR has been used to characterize the constituents of plant biomass such as lignin, hemicellulose, and others (TRACK, 1991; FAIX and BÖTTCHER, 1991). Among the various chemical functions present in lignin, such as $-\mathrm{OH}, \mathrm{CH}_{2}$ and $\mathrm{CH}_{3}$ present in aliphatic structures, carbonyl and carboxyl $\mathrm{C}=\mathrm{O},-\mathrm{C}=$ present in aromatic 
structures, -COO present in acetate, and others may be characterized by FTIR. Some studies have also been developed using the technique of near infrared spectroscopy - NIR combined with multivariate analysis for rapid characterization of biomass, allowing the analysis of the composition of hundreds of samples at a low cost (HAMES et al., 2003).

Mid-infrared spectra were obtained from hydrolysates samples from diluted sulfuric acid pretreatment of forest residues using FTIR spectrophotometer equipped with a cell of attenuated total reflectance - ATR. The analysis of the spectra by the method of partial least squares - PLS from each sample was performed. Regression analysis of sugar components and lignin were generated with the results obtained from chemical analysis and high performance liquid chromatography. The ATR-FTIR technique allowed analysis of samples in minutes, and the prediction of the composition of an unknown sample can be carried out very fast once the method is calibrated with known standards (TUCKER et al., 2001).

The determination of phenolic $\mathrm{OH}$ groups present in the lignin structure can also be made through the use of UV spectroscopy method $(\Delta \varepsilon)$, as described by ZAKIS (1994). This method is based on the difference in absorption at 300 and $360 \mathrm{~nm}$ in neutral and alkaline aqueous solutions. The technique of UV/Vis spectroscopy can also be used for determination of carbonyl groups, as described by FAIX et al. (1998).

Another technique of interest is the UV/Vis fluorescence (or photoluminescence), which is a technique that basically distinguishes $\pi$ conjugated electronic systems. The higher the conjugation of the electronic system, the greater will be the wavelengths of absorption and emission due to lower energy required to excite electrons from its fundamental state to the excited state (MILORI et al., 2004). CASTELLAN et al. (1996) present results for the lignin derivatives in different solvents. They observed that the method is able to distinguish the differences in the chromophores as a function of different interactions with the solvent.

The fluorescence spectroscopy is also a very selective technique, since both excitation and emission wavelengths depend on the same compound of interest, making the fluorescence signal collected characteristic for each molecule under study. Variations in this signal represent changes in the path taken during the decay of the excited state and can indicate the possible changes undergone by the molecule (GARBIN, 2004; GONZALEZ-PEREZ et al., 2004; CARVALHO et al., 2004; MILORI et al., 2002).

Spectroscopic methods may be used for characterization of cellulose and hemicellulose, both in extracted and raw samples of lignocellulosic material. The NMR $-{ }^{13} \mathrm{C}$ spectroscopy has enabled a lot of information about the structure of cellulose, particularly in its native state. This technique has been applied in studies about the secondary and tertiary structures of solid samples. Because the technique is sensitive to the chemical environment in which the analyte is present, the response is influenced by the degree of symmetry of material (ATALLA and ISOGAI, 1998).

Polymorphisms of cellulose can also be observed through the combined evaluation of different techniques (X ray, FTIR, and NMR). WADA et al. (2004), present results on the polymorphism of cellulose I, III and IV. They observed that the crystallinity of cellulose depends on the source material and the extraction process used.

Thermal analysis is another interesting technique for analysis of lignocellulosic material (KHAN and ASHRAF, 2007; SUN et al., 2005). The thermogravimetry technique is based on mass loss of a sample when subjected to a gradual increase of temperature. Mass loss at temperatures up to $110{ }^{\circ} \mathrm{C}$ corresponds to a loss of free water and also some volatile compounds present in the structure. Cellulose and hemicellulose are degraded at temperatures ranging from $200{ }^{\circ} \mathrm{C}$ to $400{ }^{\circ} \mathrm{C}$, depending on the degree of crystallinity of the material and how they are linked to the structure of lignin. Most of the lignin, which corresponds to the phenolic structure of the chain, is degraded at temperatures between 400 and $600{ }^{\circ} \mathrm{C}$. Through Differential Scanning Calorimetry - DSC, it is possible to observe phase changes of different crystalline states in the cellulose and hemicellulose structure (SUN et al., 2005). 
Imaging technologies such as nuclear magnetic resonance - NMR, X-ray, atomic force microscopy - AFM, scanning electron microscopy - SEM show a great potential in understanding the structure of plant cell wall.

Finally, through studies of theoretical principles and applications of EPR techniques, NMR, FTIR, NIR, absorption of UV-vis, UV-vis fluorescence and laser-induced fluorescence - LIF, certainly great advances in the understanding of the chemical characteristics biomass can be achieved, and allow a much broader, specialized and updated view on this very important and challenging subject for the present and future.

\section{Enzyme Production}

Although the enzymatic hydrolysis stands out as a route of great interest for the industrial production of cellulosic ethanol, one of the greatest challenges in this area is related to the high cost of the enzymes. The development of efficient and optimized processes for enzyme production on an industrial scale is crucial to ensuring the economic viability of the application of enzymatic route for the production of cellulosic ethanol.

The fermentation process for enzymes production can be conducted both in a liquid medium, called submerged fermentation - SF, and in a solid medium, the solid-state fermentation - SSF. The SSF is defined as the process of growing microorganisms in a solid substrate containing moisture enough to maintain growth and metabolism, i.e., without of free water (RAHARDJO et al., 2006).

Approximately 90\% of all industrial enzymes are produced by SF, often using genetically modified microorganisms (HOLKER et al., 2004). However, most of these enzymes could be produced by SSF using wild microorganisms.

In this context, the use of the SSF has been particularly advantageous for the growth of filamentous fungi, since it simulates the natural habitat of these microorganisms. This benefit is extended to the production of enzymes, providing a higher productivity when compared to submerged fermentation process. In addition, enzymes produced by the SSF are less susceptible to problems of substrate inhibition and also have greater stability to temperature and $\mathrm{pH}$ changes (HOLKER et al., 2004). From the environmental point of view, the advantage of the SSF is related to the lower volume of effluent produced and the possibility of conducting the process under semisterile conditions. Another advantage of SSF is the use of agro-industrial residues (sugarcane bagasse, wheat bran etc.) as a solid substrate, acting both as sources of carbon and energy.

Despite all these advantages of SF compared to SSF, the SSF was held back by a disadvantage that limits its application in a broader and more direct form in industrial processes: the difficulty of monitoring and controlling the different variables involved in the process. While in the SF process the medium can be considered homogenous, in FSS there are several gradients of humidity and temperature, which can negatively influence the production of metabolites. This physical variability is particular to each process, but can be analyzed with the help of technological tools available, such as distributed data acquisition of physical and chemical parameters, actuators and automation systems. Knowing the optimal conditions of each process in a certain range, means better prediction of the behavior of the process on a larger scale. In SSF, the control of temperature, humidity, $\mathrm{pH}$, water activity and gas exchange are essential for microbial growth and the consequent production of metabolites.

Among the variables involved in the process, temperature control is particularly important, since microbial growth under aerobic conditions results in a consequent release of heat, which can produce denaturation of the enzymes produced (HOLKER and LENZ, 2005) and other deleterious effects to the microorganism. Also, as SSF occurs in the absence of free water, this heat is difficult to remove due to the limited thermal conductivity of the solid substrate and the low thermal capacity of air (WEBER et al., 1999). In this sense, the mechanism of evaporation has been considered the most suitable for performing heat exchange in large-scale SSF reactors (NAGEL et al., 2001). However, evaporative cooling is accompanied by loss of moisture, which may cause dryness of the 
substrate, thus requiring the need for a combined control of temperature and humidity.

Some studies have used indirect measures for monitoring (so-called software sensors) as flow, temperature and humidity to control the temperature and the amount of water in the fermentation medium (SARGANTANIS et al., 1993; NAGEL et al., 2001; PEÑA Y LILLO et al., 2001; KHANAHMADI et al., 2006). The profiles of the aeration, along with monitoring of oxygen consumed or $\mathrm{CO}_{2}$ produced during the microbial metabolism may, through the use of mass balances and energy, generate important data related to process control.

Therefore, there is a demand for the development of instrumentation that will allow the development of a system of control and automation in SSF. This is an important step towards the development of industrial scale bioreactors, since the SSF, while showing some advantages in relation to SF for the production of enzymes, imposes a series of operational limitations that hinder its scale up.

\section{INTEGRATION OF CELLULOSIC ETHANOL PRODUCTION AIMING AT SUSTAINABILITY}

The production of ethanol from lignocellulosic materials has been investigated with great interest in recent years. However, the process on an industrial scale is not feasible yet. Studies taking into account the integration of the process, the increase in fermentation efficiency and integration of individual operations are necessary to make the hydrolysis of biomass a competitive and sustainable technology.

Several studies have highlighted the advantages of second-generation biofuels in comparison to first generation. However, depending on the energy balance and its social and economic sustainability, not all biofuels bring the benefits commonly associated with fuels from renewable energy sources, such as reducing greenhouse gas emissions.

The integration of the process through mathematical modeling and simulation of the possible configurations of the technological routes will al- low the proposition of computational solutions to optimize the operation of the process, to assess environmental and social impacts, as well as its economic viability. This will allow assessment of their phase of development and sustainability, as well as interest in its implementation.

Each of these aspects can be divided into several steps that are interlinked and should be evaluated in an integrated manner for decisionmaking, namely:

- Technological chain: production of raw materials, logistics from supply to processing, characteristics of raw materials, conversion processes, product characteristics, logistics of supply of products, use.

- Costs of production, processing, transportation, and use.

- Environmental impacts: carbon balance, energy balance, emissions, sustainability of production systems.

- The social organization of production and market, public perception, public policy framework.

The integration of the manufacturing process of cellulosic ethanol provides the possibility of restructuring the existing plants or the integration of new facilities close to existing ones. The residue of cane sugar is available at the site of the ethanol agro-industry, and with the improvement of energy co-generation technology it tends to increase their availability. Ethanol made from sugarcane bagasse can be produced in the same location as the conventional ethanol made from sugar, using the units of fermentation and distillation in an integrated form, which would result in lower production costs. In general, the integration can be performed at different levels, namely:

- equipment sharing;

- energy integration (sharing of current heat exchange, industry utilities etc.);

- reuse of materials, recycling streams;

- integrated wastewater treatment.

In addition, the development of mathematical modeling tools of the operations involved in the various processes in analysis will identify the needs of instrumentation, and will allow the implemen- 
tation of modern techniques of process control at industrial level (BONOMI, 2008).

There are some commercially available simulation packages (ASPEN Plus, SuperPro Designer and Hysys) that were developed for a wide spectrum of industries such as pharmaceutical, biotechnology, fine chemicals, mineral processing, microelectronics, waste treatment and others. Some of the desirable characteristics of these simulation packages should be adapted to meet the objectives of the integration of the cellulosic ethanol production (BONOMI, 2008). There is also a strong demand for software development with a database of the composition of different types of biomass and physical-chemical properties of the different components involved in the process, from sugars to fermentation inhibitors.

WOOLEY and PUTSCH (1996) performed the structuring of a database of physical and chemical properties of the main components involved in the production of ethanol from wood to the simulation software Aspen Plus. This work was carried out by National Renewable Energy Laboratory - NREL - in the United States with the idea of providing a basis for all simulations in this software by the research groups involved in the project. Properties such as critical temperature, critical pressure, enthalpy of formation, density, heat capacity and vapor pressure of some key components such as ethanol, glucose, xylose, cellulose, lignin and cellulose were added to the database.

NAGLE et al. (1999) used the Aspen Plus software to perform an economic evaluation of an alternative configuration of the process of hydrolysis of a cellulosic material (the grass yellow poplar) using a step of two stages pretreatment, a unit of adsorption of lignin and a co-fermentation for the simultaneous fermentation of pentoses and hexoses hydrolyzate with a recombinant strain of Z. mobilis. The simulation results allowed selecting the optimum conditions of key variables on a bench scale for the future definition of a more advanced project on a larger scale.

CARDONA and SANCHEZ (2004, and 2006) studied the simulation of different process configurations for the production of cellulosic ethanol from wood including variations in the pre- treatment, hydrolysis of cellulose, fermentation, separation and wastewater treatment, taking into account possibilities for process integration. The simulations were performed using the software Aspen Plus, comparing the energy expenses of different settings. The results showed that the most appropriate case would be a process with the following sequence of unit operations: pretreatment with dilute acid, simultaneous saccharification and fermentation of pentoses and hexoses, coupled with pervaporation distillation and recycling of the water used in the process. The need to consider the effect of inhibitors on the co-fermentation and the number of current recycling was highlighted in the sensitivity analysis.

The recycling of some of the process streams should also be evaluated for integration. Recycling of sugar chains, as well as the reuse of cellulolytic enzymes, offer great opportunities to reduce process costs. The suggestion for recycling of cellulases was reported by MES-HARTREE et al. (1987). These authors suggest the use of cellulases and the residual substrate in the step of cellulases production. GALBE and ZACCHI (1994) studied the recycling of pentose formed during the hydrolysis of hemicellulose and obtained an increase in ethanol production and a decrease in energy consumption. LEE et al. (1995) proposed the reuse of cellulases by different strategies of recycling from the residual substrate hydrolysis step of cellulose. The authors reported that the presence of lignin in the substrate negatively affected the activity of cellulase.

Whereas the existing technologies for the conversion of biomass into cellulosic ethanol are not fully developed in comparison with first generation ethanol, the development of software to facilitate process integration and the validation of mathematical models by experimental tests, can provide important tools for the design of optimal configurations, along with the best technical/economic, environmental and social indicators.

\section{BIO-REFINERY: A VISION OF THE FUTURE}

The concept of biorefineries, despite being defined in different ways by some sectors, expresses 
the consensual idea of processes integration in order to convert biomass into fuel, energy and chemicals. In other words, the concept is similar to that of oil refineries, in which crude oil are converted into different products for different applications in an integrated and optimized system. The concept of industrial biorefineries has been identified as the most promising route for the establishment of future new industries.

The conversion of renewable energy sources in the biorefineries can be accomplished primarily through three routes:

(1) The thermo-chemical route, which includes the processes of biomass pyrolysis, gasification.

(2) The chemical route, acid hydrolysis of biomass, production of poly (lactic acid).

(3) The biochemical route, including enzymatic catalysis and fermentation.
Biocatalysis or enzymatic catalysis is a technology that has been considered key in the biorefinery processes due to milder operating conditions and higher conversion efficiency. The biocatalysts can be applied in the production of biofuels ethanol and biodiesel, as well as in the synthesis of biodegradable plastics such as polyesters. An idea of the diversity of products with potential to be obtained from biorefineries is shown in Figure 2 (KAMM et al., 2006).

Some studies have been done proposing the integration of the concept of biorefineries with the systems of agriculture and livestock (SENDICH et al., 2008). The incorporation of these systems will allow an environmental and economic integrated analysis of biomass conversion into different products, fertilizers and ethanol. The authors present a comparison of the performance of various simulation models with different crops using

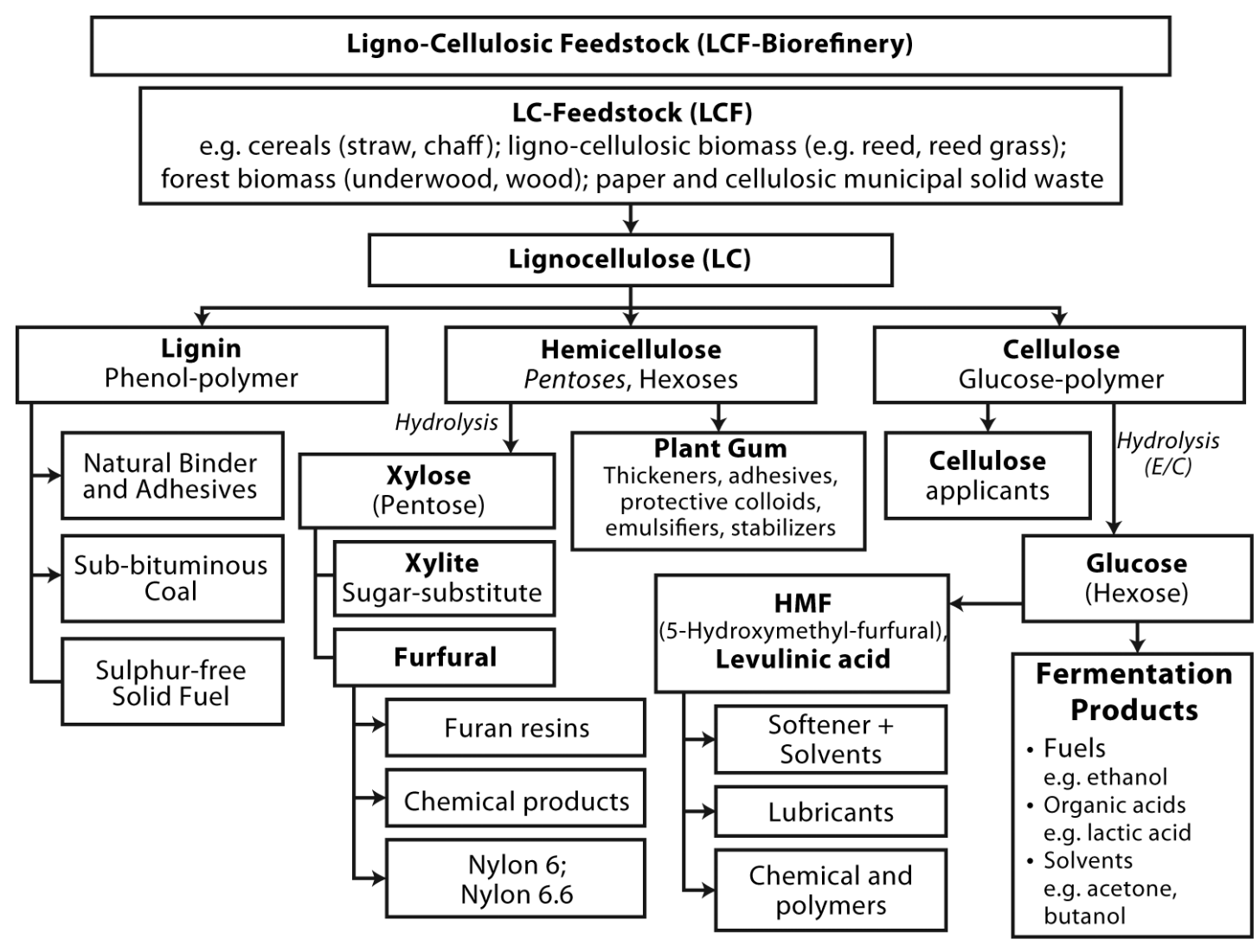

Source: KAMM et al., 2006.

FIGURE 2 Products from biorrefineries. 
some software already available in the market (DAYCENT, Integrated Farm System Model - IFSM and I-FARM) and suggest a model to be used in selecting the best alternative strategy together with the current methods of process engineering.

BONOMI (2008) proposed the concept of a Virtual Biorefinery, which has the purpose of building/adapting simulation software in order to facilitate the modeling, optimization and technical-economic assessment and sustainability of integrated processes, the main characteristic of a biorefinery. According to the author, the Virtual Biorefinery system is a computational tool that will simulate the behavior of a standard biorefinery and its various concepts (making even possible the continuous addition of new strategies for materials and processes used and products generated).

In the technical and scientific literature there are several reports regarding the mathematical modeling and simulation of various operations of the biorefinery (SADHUKHAN et al., 2008; ARIFEEN et al., 2008; SENDICH et al., 2008). It is necessary for the construction of the Virtual Biorefinery to evaluate the proposed models, adapting them to compose the various alternatives for biorefinery, to develop the models that have not yet been developed (regarding the technologies employed and those in development) and, finally, enter all the models available in the simulation platform - on the virtual biorefinery. As an illustration below are some examples of models available in the literature that fit the needs of the construction of virtual biorefineries (BONOMI, 2008):

- fermentation industry;

- production of polyhydroxyalkanoates;

- production of ethanol from starch;

- simultaneous saccharification and fermentation of lignocellulosic material.

A typical composition of lignocellulosic materials (in dry mass) is $35 \%$ to $50 \%$ cellulose, $20 \%$ to 35\% hemicellulose and 5\% to 30\% lignin (LYND et al., 1999). Thus, using only cellulose can result in a significant amount of unused material as a byproduct of lesser value or waste. This will lead to a strong impact on both the conversion efficiency, and in the economy of the whole process. Lignin is the second most abundant renewable and sustain- able source of carbon, along with cellulose, and development of technologies for its conversion should be considered.

One possible use of lignin in the biorefinery concept was proposed by KLEINERT and BARTH (2008). The authors studied mixtures of formic acid and alcohol in the reaction medium for conversion of lignin in "liquid oils". The authors report a new liquefaction process that is able to depolymerize lignin in a liquid bio-oil with low oxygen content that can be used as a component to be mixed with conventional fossil fuels.

In addition to the technical and economic issues, the impact related to environmental and social gains arising from the implementation of biorefineries has been analyzed by the methodology of life cycle analysis. UIHLEIN and SCHEBEK (2009) carried out the assessment of the life cycle of a refinery using lignocellulosic raw material, analyzing different configurations of process and products. The best configuration resulted in yields better than the alternatives from renewable fuels, with the total environmental impacts about $41 \%$ lower. For most of the configurations of biorefinery analyzed, the environmental performance was better than the fossil fuel comparable.

In conclusion, the development of biorefineries opens perspectives for the production of a large number of products derived from biomass that can replace oil products as well as some products that can not be manufactured in conventional refineries. There is, therefore, a great potential for the biorefineries of the future to be competitive with existing fossil alternatives from technical-economic and environmental point of view, especially when the technologies are improved.

\section{ACKNOWLEDGMENTS}

This chapter was based on two round tables entitled Virtual Biorefinery - Tool for Sustainability Assessment of Different Proposals for a Biorefinery and Stage of Development of New Technologies and Second generation ethanol - challenges for the instrumentation and automation, occurred during the Workshop Instrumentation and Automation in Agriculture and In- 
dustrial Sugarcane Ethanol Chain, on 11.29.2008, at Embrapa Agricultural Instrumentation, São Carlos, SP. The authors gratefully acknowledge the contributions of the speakers and panelists participating, namely Antonio Bonomi from the Center of Bioethanol Science and Technology, Flavio Vasconcellos da Silva from School of Chemical
Engineering at Unicamp, André Bello de Oliveira, from Petrobras, Ronaldo Nobrega from PAM selective membranes, Ibrahim Daniel Atala from the Center for Sugarcane Technology, Cristina Maria Monteiro Machado from Embrapa Agroenergy and Teresa Zangirolami from Department of Chemical Engineering at UFSCar.

\section{REFERENCES}

ARIFEEN, N.; WANG, R.; KOOKOS, I. K.; WEBB, C.; KOUTINAS, A. A. Process Design and Optimization of Novel Wheat-Based Continuous Bioethanol Production System. Biotechnology Progress, v. 23, p. 1394-1403, 2007.

ATALA, D. I. P. Montagem, instrumentação, controle e desenvolvimento experimental de um processo fermentativo extrativo de produção de etanol. 2004. Tese (doutorado) - Universidade Estadual de Campinas. Faculdade de Engenharia de Alimentos, 2004.

ATALLA, R. H.; ISOGAI, A. Recent Developments in Spectroscopic and Chemical Characterization of Cellulose. In: S. DUMITRIU. Polysaccharides: structural diversity and functional versatility. 2 ed. Marcel Decker. p. 123-157. 1998.

BOLTON, J. R. Electron spin resonance theory. In: WEIL, J. A.; BOLTON, J. R. Electron paramagnetic resonance: elementary theory and practical applications. New York, Willey, cap. 1, p. 11-61, 1994.

BONOMI, A. 2008. XVII Workshop - Instrumentação e Automação Agrícola e Agroindustrial. Disponível em: $<$ http://www.apta.sp.gov.br/cana/anexos/position_paper_instrumentacao_1_Bonomi.pdf>. Acesso em: 08 mar. 2009.

BRUGNOLLO, E. D.; PATERNO, L. G.; LEITE, F. L.; FONSECA, F. J.; CONSTANTINO, C. J. L.; ANTUNES, P. A.; MATTOSO, L. H. C. Fabrication and characterization of chemical sensors made from nanostructured films of poly(o-ethoxyaniline) prepared with different doping acids. Thin Solid Films, v. 516, p. 3274-3281, 2008.

CARDONA, C. A.; SANCHEZ, O. J. Energy consumption analysis of integrated flowsheets for production of fuel ethanol from lignocellulosic biomass. Energy, v. 31 (13), p. 2447-2459, 2006.

CARDONA, C.; SANCHEZ, O. 2004. Analysis of integrated flow sheets for biotechnological production of fuel ethanol. In: PRES 2004 - XVI International Congress of Chemical and Process Engineering (CHISA 2004), Prague, Czech Republic.
CARVALHO, E. R.; FILHO, N. C.; VENANCIO, E. C.; OSVALDO, N. O.; MATTOSO, L. H. C.; MARTIN-NETO, L. Detection of brominated by-products using a sensor array based on nanostructured thin films of conducting polymers. Sensors, v. 7, p. 3258-3271, 2007.

CARVALHO, E. R.; MARTIN-NETO, L.; MILORI, D. M. B. P. et al. Interactions of chlorine with tropical aquatic fulvic acids and formation of intermediates observed by fluorescence spectroscopy. J. Braz. Chem. Soc., v. 15, n. 3, p. 421-426, 2004.

CASTELLAN, A.; GRELIER, S.; KESSAB, L.; NOURMAMODE, A.; HANNACHI, Y. Photophysics and photochemistry of a lignin model molecule containing a-carbonyl guaiacyl and 4-hydroxy-3-methoxybenzyl alcohol moieties. J. Chem. Soc., Perkin Trans. 2, p. 1131-38, 1996.

CZECHOWSKI, F.; GOLONKA, I.; JEZIERSKI, A. Organic matter transformation in the environment investigated by quantitative electron paramagnetic resonance (EPR) spectroscopy: studies on lignins, Spectrochimica Acta. Part A, v. 60, 2004, p. 1387-1394.

EVELEIGH, D. E. Cellulase: a perspective. Phil. Trans. $R$. Soc. Lond. Ser. A. v. 321, p. 435-447, 1987.

FAIX, O. Holzforschung, 45, 21, 1991.

FAIX, O.; ANDERSONS, B.; ZAKIS, G. Determination of carbonyl groups of six round robin lignins by modified oximation and FTIR spectroscopy. Holzforschung, v. $52,268-274,1998$

FAIX, O.; BÖTTCHER, J. H. Holzforschung, 47, 45, 1991. FELIPE, M. G. A. 2006. I Workshop - Produção de Etanol. Disponível em: <http://www.apta.sp.gov.br/cana/ ver_work.php?work_id=41>. Acesso em: 08 mar. 2009. FERREIRA, E. J.; PEREIRA, R. C. T.; DELBEM, A. C. B.; OLIVEIRA, O. N.; MATTOSO, L. H. C. Random subspace method for analysing coffee with electronic tongue.

Electronics Letters, v. 43, p. 1138-1140, 2007.

FERREIRA, M.; RIUL, A.; WOHNRATH, K.; FONSECA, F. J.; OliveIRA, O. N.; MATTOSO, L. H. C. High-per- 
formance taste sensor made from Langmuir-Blodgett films of conducting polymers and a ruthenium complex. Analytical Chemistry, v. 75, p. 953-955, 2003.

FIALHO, L. L. Caracterização da matéria orgânica em processo de compostagem por métodos convencionais e espectroscópicos. 2007. 170 p. Tese (Doutorado) - Instituto de Química, Universidade de São Paulo, São Carlos, 2007.

FIALHO, L. L.; FRANCISCO, R. A.; SIMÕES, M. L.; DA SILVA, W. T. L.; MARTIN-NETO, L. Interferência da lignina na quantificação de radicais livres no processo de compostagem, VII Encontro Brasileiro de Substâncias Húmicas, Florianópolis, 40, 2007.

FITZPATRICK, J. D.; STEELINK, C. The origin of the paramagnetic species in lignin solutions. Autoreduction of 2,6-dimethoxybenzoquinone and related quinines to radical anions in alkaline solution, Journal of Organic Chemistry, v. 37, p. 762-767, 1972.

GALBE, M.; ZACCHI, G. Simulation of ethanol production processes based on enzymatic hydrolysis of woody biomass. Computers and Chemical Engineering 18 (suppl), p. S687-S691, 1994.

GARBIN, J. R. Estudos espectroscópicos da fotólise de pesticidas em água na presença de substâncias húmicas. 2004. 90 f. Tese (Doutorado em Ciência e Engenharia de Materiais). Interunidades (EESC/IFSC/ IQSC) - Universidade de São Paulo, São Carlos, SP, 2004.

GONZÁLEZ-PÉREZ, M.; MARTIN-NETO, L.; SAAB, S. C.; NOVOTNY, E. H.; MILORI, D. M. B. P.; BAGNATO, V. S.; COLNAGO, L. A.; MELO, W. J.; KNICKER, H. Characterization of humic acids from a Brazilian Oxisol under different tillage systems by EPR, 13C NMR, FTIR and fluorescence spectroscopy. Geoderma, Amsterdam, v. 118, p. 181-190, 2004.

HAMES, B. R.; THOMAS, S. R.; SLUITER, A. D.; ROTH, C. J.; TEMPLETON, D. W. Rapid Biomass Analysis. Applied Biochemistry and Biotechnology, v. 105, p. 5-16, 2003

HARMS, P.; KOSTOV, Y.; RAO, G. Bioprocess monitoring. Current Opinion in Biotechnology, 13, p. 124-127, 2002.

HÖLKER, U.; HÖFER, M.; LENZ, J. Biotechnological advantages of laboratory-scale solid-state fermentation with fungi. Applied Microbiology and Biotechnology, v. 64, p. 175-186, 2004.

HOLKER, U.; LENZ, J. Solid-state fermentation - are there any biotechnological advantages? Current Opinion in Microbiology, v. 8, p. 301-306, 2005.
KAMM, B.; GRUBER, P.; KAMM, M. Biorefineries - Industrial Processes and Products, vol. 1, Wiley-VCH, 2006.

KHAN, M. A.; ASHRAF, S. M. Studies on thermal characterization of lignin: Substituted phenol formaldehyde resin as wood adhesives. Journal of Thermal Analysis and Calorimetry, v. 89, p. 993-1000, 2007.

KHANAHMADI, M. et al., Bed moisture by monitoring of air stream temperature rise in packed-bed solid-state fermentation. Chemical Engineering Science, v. 61, p. 5654-5663, 2006.

KLEINERT, M.; BARTH, T. Towards a Lignincellulosic Biorefinery: Direct One-Step Conversion of Lignin to Hydrogen-Enriched Biofuel, Energy \& Fuels, v. 22, p. 1371-1379, 2008.

KNAUF, M.; MONIRUZZAMAN, M. Lignocellulosic biomass processing: A perspective. International Sugar Journal, v. 106, n. 1263, p. 147-150, 2004.

LEE, D.; YU, A. H. C.; SADDLER, J. N. Evaluation of cellulase recycling strategies for the hydrolysis of lignocellulosic substrates. Biotechnology and Bioengineering, v. 45, p. 328-336, 1995.

LYND, L. R.; WYMAN, C. E.; GERNGROSS, T. U. Biocommodity engineering. Biotechnology Progress, v. 15, p. 777-793, 1999.

MACEDO, I. C. 2003. Estado da arte e tendências das tecnologias para energia. Disponível em: <http://www. finep.gov.br/fundos_setoriais/ct_energ/documentos/ ct-energ03estado_arte.pdf>. Acesso em: 08 mar. 2009.

MARTIN-NETO, L.; ANDRIULO, A. E.; TRAGHETTA, D. G. Effects of cultivation on ESR spectra of organic matter from soil size fractions of a Mollisol, Soil Science, v. 157, p. 365-372, 1994.

MARTIN-NETO, L.; ROSSEL, R.; SPOSITO, G. Correlation of spectroscopic indicators of humification with mean annual rainfall along a temperate grassland climosequence. Geoderma, Amsterdam, v. 81, n. 3/4, p. 305-311, 1998.

MARTIN-NETO, L.; TRAGHETTA, D. G; VAZ, C. M. P.; CRESTANA, S.; SPOSITO, G. On the interaction mechanisms of atrazine and hydroxyatrazine with humic substances. Journal of Environmental Quality, v. 30, p. 520-525, 2001.

MARTIN-NETO, L.; VAZ, C. M. P.; CRESTANA, S. (editores) Instrumentação avançada em ciência do solo. Embrapa Instrumentação Agropecuária, São Carlos/SP, 2007. 438 p. ISBN: 85-86463-14-0.

MES-HARTREE, M.; HOGAN, C. M.; SADDLER, J. N. Recycle of enzymes and substrate following enzymatic hydrolysis of steam-pretreated aspenwood. Biotechnology and Bioengineering, v. 30, 558-564, 1987. 
MILORI, D. M. B. P.; MARTIN-NETO, L.; BAYER, C.; MIELNICZUCK, J.; BAGNATO, V. S. Humification degree of soil humic acids determined by fluorescence spectroscopy. Soil Science, v. 167, n. 11, p. 739-749, 2002.

NAGEL, F-J. J. I. et al. Temperature control in a continuosly mixed bioreactor for solid-state fermentation. Biotechnology and Bioengineering, v. 72, n. 2, p. 219-230, 2001.

NAGLE, N.; IBSEN, K.; JENNINGS, E. A process economic approach to develop a dilute-acid cellulose hydrolysis process to produce ethanol from biomass. Applied Biochemistry and Biotechnology, v. 77-79, p. 595607, 1999.

OGIER, J. C.; BALLERINI, D.; LEYGUE, J.-P.; RIGAL, L.; POURQUIÉ, J. Production d'éthanol à partir de biomasse lignocellulosique. Oil Gas Sci Technol, v. 54, n. 1, p. 67-94, 1999.

OLIVEIRA, A. B. Comunicação Pessoal. 2009.

PENA y LILLO, M. et al. Indirect measurement of water content in na aseptic solid substrate cultivation pilotscale bioreactor. Biotechnology and Bioengineering, v. 76, n. 1, p. 44-51, 2001.

PINTO, G. A. Biorrefinaria de soro de queijo: engenharia de bioprocessos e sistemas aplicada à transformação de um resíduo poluente em produtos com valor agregado. 2008. Tese (Doutorado em Engenharia Química) - Universidade Federal de São Carlos, 2008.

PINTO, G. A.; GIORDANO, R. L. C.; GIORDANO, R. C. Remote engineering for a cheese whey biorefinery: an Internet-based application for process design, economic analysis, monitoring, and control of multiple plant sites. Bioprocess and Biosystems Engineering, v. 32, p. 69-78, 2009

PRESTON, C. M. Applications of NMR to soil organic matter analysis: history and prospects. Soil Science, v. 161, n. 3, p. 144-166, 1996.

RAHARDJO, Y. S. P.; TRAMPER, J.; RINZEMA, A. Modeling conversion and transport phenomena in solid-state fermentation: A review and perspectives. Biotechnology Advances, v. 24, p. 161-179, 2006.

RIUL, A.; MALMEGRIM, R. R.; FONSECA, F. J.; MATTOSO, L. H. C. An artificial taste sensor based on conducting polymers. Biosensors \& Bioelectronics, v. 18, p. 13651369, 2003.

RUDNITSKAYA, A.; LEGIN, A. Sensor systems, electronic tongues and electronic noses, for the monitoring of biotechnological processes. Journal of Industrial Microbiology and Biotechnology, v. 35, p. 443-451, 2008.

SAAB, S. C.; CONCEIÇÃO, M.; MARTIN-NETO, L. Espectroscopia de FTIR e EPR em solos inteiros (gleissolos) e ácidos húmicos. In: Simpósio Nacional de Instrumentação Agropecuária, 2, 2000, São Carlos, SP. Anais do II Siagro. São Carlos, SP: Embrapa Instrumentação Agropecuária, 1998. p. 366-370.

SADHUKHAN, M. A.; MUSTAFA, N.; MISAILIDIS, F.; MATEOS-SALVADOR, C.; DU, G. M. Campbell Value analysis tool for feasibility studies of biorefineries integrated with value added production, J. Chemical Engineering Science, v. 63, p. 503-519, 2008.

SARGANTANIS, J. et al. Effect of operating conditions on solid substrate fermentation. Biotechnology and Bioengineering, v. 42, n. 2, p. 149-158, 1993.

SCHNITZER, M.; KHAN, S. U. Humic substances chemistry and reactions: soil organic matter. New York: Elsevier, p. 319, 1978.

SENDICH, E. D.; DALE, B. E.; KIM, S. Comparison of crop and animal simulation options for integration with the biorefinery, Biomass and Bioenergy, v. 32, p. 11621174, 2008.

SENESI, N. Application of electron spin resonance (ESR) spectroscopy in soil chemistry. Adv. Soil. Sci., v. 14, p. 77-130, 1990.

STEVENSON, F. J. Humus Chemistry: genesis, composition, reactions, 2. ed. New York: John Wiley, p. 496, 1994.

SUN, X. F.; XU, F.; SUN, R. C.; GENG, Z. C.; FOWLER, P.; BAIRD, M. S. Characteristics of degraded hemicellulosic polymers obtained from steam exploded wheat straw. Carbohydrate Polymers, v. 60, p. 15-26, 2005.

TUCKER, M. P.; NGUYEN, Q. A.; EDDY, F. P.; KADAM, K. L.; GEDVILAS, L. M.; WEBB, J. D. Fourier Transform Infrared Quantitative Analysis of Sugars and Lignin in Pretreated Softwood Solid Residues. Applied Biochemistry and Biotechnology, v. 91-93, p. 51-61, 2001.

UIHLEIN, A.; SCHEBEK, L. Environmental impacts of a lignocellulose feedstock biorefinery system: an assessment, 2009.

VEALE, E. L.; IRUDAYARAJ, J.; DEMIRCI, A. An on-line approach to monitor ethanol fermentation using FTIR spectroscopy. Biotechnology Progress, v. 23, p. 494$500,2007$.

VOJINOVI, V.; CABRAL, J. M. S; FONSECA, L. P. Real-time bioprocess monitoring Part I: In situ sensors. Sensors and Actuators B, v. 114, p. 1083-1091, 2006.

WADA, M.; HEUX, L.; SUGIYAMA, J. Polymorphism of Cellulose I Family: Reinvestigation of Cellulose IV. Biomacromolecules, v. 5, p. 1385-1391, 2004.

WALKER, L. P.; WILSON, D. B. Enzymatic hydrolysis of cellulose: An Overview. Bioresouce Technology, v. 36, p. 3-14, 1991. 
WEBER, F. J. et al. A simplified material and energy balance approach for process development and scale-up of coniothyrium minitans conidia production by solid-state cultivation in a packed-bed reactor. Biotechnology and Bioengineering, v. 65, n. 4, p. 447-458, 1999.

WOOLEY, R.; PUTSCHE, V. 1996. Development of an ASPEN PLUS Physical Property Database for Biofuels
Components. National Renewable Energy Laboratory, Golden, CO, USA, $38 \mathrm{p}$.

WYMAN, C. E. Biomass ethanol: technical progress, opportunities, and commercial challenges. Annual Review of Energy and the Environment, v. 24, p. 189-226, 1999. ZAKIS, G. L. Functional Analysis of Lignins and Their Derivatives. Tappi Press, Atlanta, GA, 1994. 
